\title{
Możliwość zwolnienia z opodatkowania dochodów z transakcji zabezpieczających ryzyko walutowe $w$ działalności gospodarczej prowadzonej na podstawie decyzji o wsparciu lub na terenie specjalnej strefy ekonomicznej na podstawie zezwolenia
}

\begin{abstract}
An exemption from taxation of an income arising from financial instruments hedging foreign exchange risk in business activities conducted on the basis of a decision on support or in a special economic zone on the basis of a permit
\end{abstract}

Streszczenie. Celem niniejszego artykułu jest odpowiedź na pytanie, czy dochody z transakcji zabezpieczających zmiany kursów walut, tj. kontraktów terminowych typu forward i opcji walutowych, mogą być uznane za dochód z działalności gospodarczej prowadzonej na podstawie Zezwolenia SSE lub jako dochód z działalności gospodarczej określonej w decyzji o wsparciu. Zdaniem autorki 
dochody z kontraktów na zakup lub sprzedaż waluty zawieranych w celu zabezpieczenia ryzyka walutowego podlegają zaliczeniu do dochodów z działalności zwolnionej z opodatkowania podatkiem dochodowym od osób prawnych, o ile transakcje służyły zabezpieczeniu dochodów z działalności określonej w Zezwoleniu SSE lub decyzji o wsparciu. Zastosowano metodę empiryczną i analityczną w odniesieniu do podstawowych aktów prawnych regulujących omawianą tematykę, literatury przedmiotu oraz interpretacji indywidualnych prawa podatkowego, objaśnień podatkowych i wyroków sądów administracyjnych.

Słowa kluczowe: Specjalna Strefa Ekonomiczna; decyzja o wsparciu; pochodne instrumenty finansowe; ryzyko walutowe; różnice kursowe.

\begin{abstract}
This article aims to answer the question whether an income arising from financial instruments hedging foreign exchange risk, i.e. the income from forward contracts and currency options, can be considered as an income from an economic activity conducted on the basis of a Special Economic Zone (SEZ) Permit or an economic activity specified in the decision on support. In the Author's opinion, the income from contracts for the purchase or sale of foreign currencies constitutes the income from tax-exempt activities, provided that transactions were used to hedge foreign exchange risk related to activities specified in the SEZ Permit or the decision on support. This is a tantamount to the possibility of exempting such an income from corporate income tax. The empirical and analytical method was applied for the purpose of the analysis of legal acts regulating the discussed subject. Literature, individual interpretations of tax law, tax explanations, and judgments of administrative courts were used as well.
\end{abstract}

Keywords: Special Economic Zone; decision on support; derivative financial instruments; currency risk; exchange rate differences.

\title{
1. Wstęp
}

Z uwagi na to, że w ostatnich latach eksport i import w międzynarodowym handlu towarami i usługami stale się zwiększają ${ }^{1,2}$, przedsiębiorcy

1 Międzynarodowy handel usługami Polski w 2014 roku, Międzynarodowy handel usługami Polski w 2015 roku, Międzynarodowy handel usługami Polski w 2016 roku, Międzynarodowy handel usługami Polski w 2017 roku, Międzynarodowy handel usługami Pol- 
prowadzący działalność gospodarczą, którzy działają na rynku międzynarodowym, podejmują szereg różnych działań mających na celu utrzymanie rentowności prowadzonej działalności.

W związku z tym szczególnie istotne jest zabezpieczenie się przed jednym z najważniejszych ryzyk w handlu zagranicznym - ryzykiem walutowym. Jednym ze sposobów ograniczenia ryzyka związanego z dokonywaniem z kontrahentami transakcji w walutach obcych i zmiennością kursów na rynku walutowym są instrumenty finansowe, takie jak kontrakty terminowe typu forward i opcje walutowe. Najpopularniejszym instrumentem zabezpieczającym jest transakcja forward ${ }^{3}$.

W stanach faktycznych interpretacji indywidualnych przepisów prawa podatkowego oraz orzeczeń sądów administracyjnych, które były przedmiotem badania, przedsiębiorcy posiadający Zezwolenie SSE ${ }^{4}$ lub decyzję o wsparciu ${ }^{5}$ wskazywali, że zawierają walutowe kontrakty terminowe typu forward oraz kontrakty na opcje walutowe. Instrumenty te umożliwiają im w określonej dacie w przyszłości zakupienie lub sprzedanie waluty ${ }^{6}$. Celem zawierania tych kontraktów jest zabezpieczanie ryzyka walutowego związanego z dokonywanymi i otrzymywanymi płatnościami w walutach obcych, dotyczącymi bieżącej działalności operacyjnej, która

ski w 2018 roku, Międzynarodowy handel usługami Polski w 2019 roku, Narodowy Bank Polski, https://www.nbp.pl/home.aspx?f=/statystyka/mhu.html (dostęp: 28.12 .2020 r.).

2 Obroty towarowe handlu zagranicznego ogółem i według krajów w 2017 roku, Obroty towarowe handlu zagranicznego ogótem i według krajów w 2018 roku, Obroty towarowe handlu zagranicznego ogółem i według krajów w 2019 roku, Główny Urząd Statystyczny https://stat.gov.pl (dostęp: 28.12.2020 r.).

3 Zabezpieczenia przed wahaniami kursów walut, Artur Osiecki, Rzeczpospolita, 2018, https:/www.rp.pl/Finanse/306279904-Zabezpieczenia-przed-wahaniami-kursow-walut.html (dostęp: 28.12.2020).

4 Chodzi o zezwolenie na prowadzenie działalności gospodarczej na terenie danej strefy uprawniające do korzystania z pomocy publicznej, o którym mowa w art. 16 ustawy z dnia 20 października 1994 r. o specjalnych strefach ekonomicznych (Dz.U. z 2020 r. poz. 1670), dalej: „u.s.s.e.”

5 Chodzi o decyzję o wsparciu (dalej jako „DoW”), o której mowa w art. 13 ustawy z dnia 10 maja 2018 r. o wspieraniu nowych inwestycji (Dz.U. z 2020 r. poz. 1752), dalej jako „u.w.n.i.”

6 Przykładowo: Interpretacja indywidualna Dyrektora Izby Skarbowej w Warszawie z dnia 20 marca 2013 r., IPPB3/423-555/11-6/S/13/MS. 
podlega zwolnieniu z podatku dochodowego na podstawie Zezwolenia SSE lub DoW.

Konieczna jest weryfikacja, czy dochody z realizacji kontraktów forward i opcji będą podlegać opodatkowaniu, jeżeli zawierane są przez przedsiębiorców wyłącznie w celu zabezpieczenia ryzyka walutowego związanego z działalnością określoną w Zezwoleniu SSE lub DoW i nie są to kontrakty o charakterze spekulacyjnym.

\section{Charakterystyka instrumentów finansowych - kontrakty terminowe typu forward i opcje}

Definicja legalna instrumentów finansowych zawarta w art. 2 ust. 1 ustawy z dnia 29 lipca 2005 r. o obrocie instrumentami finansowymi ${ }^{7}$ jest definicją zakresową pełną. W treści przedmiotowego przepisu ustawodawca zawarł zamknięty pod względem formalnym katalog podstawowych instrumentów finansowych. W konsekwencji wyróżnione zostały papiery wartościowe oraz szczegółowo określone instrumenty finansowe niebędące papierami wartościowymi ${ }^{8}$. Do drugiej z wymienionych kategorii zalicza się m.in. instrumenty pochodne, którymi zgodnie z art. 3 pkt 28a u.o.i.f. są opcje, kontrakty terminowe, swapy, umowy forward oraz inne prawa majątkowe, których cena lub wartość zależy bezpośrednio lub pośrednio od ceny lub wartości instrumentów finansowych, walut, stóp procentowych, rentowności, indeksów finansowych, wskaźników finansowych, towarów, zmian klimatycznych, stawek frachtowych, poziomów emisji, stawek inflacji lub innych oficjalnych danych statystycznych, a także innych aktywów, praw, zobowiązań, indeksów lub wskaźników, oraz instrumenty pochodne dotyczące przenoszenia ryzyka kredytowego.

Umowy na czas przyszły (futures), umowy przedterminowe (forward), umowy opcji (options), a także umowy zamiany (swap) stanowią cztery podstawowe rodzaje derywatów, czyli konstruktów prawa cywilne-

Dz.U. z 2020 r. poz. 89, ze zm.; dalej: u.o.i.f.

M. Spyra, Prawo rynku instrumentów finansowych. Zagadnienia ogólne [w:] M. Stec (red.), Prawo instrumentów finansowych. System Prawa Handlowego Tom 4, Warszawa 2016, s. 28. 
go wiążących wartość świadczenia z wartością instrumentu bazowego ${ }^{9}$. Ustawodawca nie definiuje pojęć poszczególnych rodzajów derywatów. W związku z tym, aby dokonać wykładni tych pojęć, należy w pierwszej kolejności wziąć pod uwagę ich znaczenie wypracowane w doktrynie oraz orzecznictwie, a jeżeli takiego nie ma, należy sięgnąć do słownika ogólnego języka polskiego i powszechnie przyjętego znaczenia danego wyrażenia ${ }^{10}$. Istotne jest również zwrócenie uwagi na aspekty praktyczne obrotu instrumentami finansowymi, co powoduje konieczność uwzględnienia znaczeń nadanych przedmiotowym pojęciom na rynkach finansowych ${ }^{11}$.

Dlatego w ocenie autorki zasadne jest przedstawienie krótkiej charakterystyki wybranych instrumentów finansowych. Umowy typu forward należą do podstawowych transakcji terminowych ${ }^{12}$. Kontrakt forward to umowa dwustronnie zobowiązująca do zakupu lub sprzedaży określonej ilości dobra bazowego (np. towaru, waluty) na indywidualnie określonych warunkach, po ustalonej z góry cenie, w umówionym terminie realizacji. Zawierane są poza rynkiem zorganizowanym i co do zasady nie są przedmiotem obrotu wtórnego. Kontrakty forward mają przede wszystkim chronić przed następującymi ryzykami: kursowym na rynku walutowym, zmian ceny danego towaru na rynku, a także stopy procentowej ${ }^{13}$. Wystawca oraz nabywca kontraktu terminowego forward są wobec siebie jednocześnie wierzycielem i dłużnikiem.

Dla celów niniejszego opracowania kluczowe znaczenie mają m.in. kontrakty typu forward, których istota polega na ustaleniu z góry kursu danej waluty, według którego strony dokonają rozliczeń w określonym

$9 \quad$ K. Glibowski, komentarz do art. 2 [w:] M. Wierzbowski, L. Sobolewski, P. Wajda (red.), Prawo rynku kapitałowego. Komentarz., Warszawa 2018, System Informacji Prawnej Legalis.

10 A. Choduń, Koncepcja wykładni prawa Macieja Zielińskiego, „Ruch Prawniczy, Ekonomiczny i Socjologiczny” 2016, nr 4, s. 61.

11 M. Spyra, Prawo rynku instrumentów finansowych... s. 12.

12 A. Chłopecki, Wprowadzenie - prawa pochodne jako instrumenty finansowe [w:] A. Chłopecki, Opcje i transakcje terminowe. Zagadnienia prawne, Warszawa 2001, LEX.

13 A. Świderski, Pochodne oraz strukturyzowane instrumenty finansowe - „sprawcy” czy „ofiary” ostatniego kryzysu finansowego? [w:] E. Fojcik-Mastalska, E. Rutkowska-Tomaszewska (red.), Bezpieczeństwo rynku finansowego, Wrocław 2010, s. 108. 
terminie w przyszłości dla określonej z góry kwoty kapitału. W przypadku kontraktu rzeczywistego forward jego rozliczenie nastąpi poprzez zamianę aktywów (złotych na walutę lub odwrotnie) ${ }^{14}$. Kontrakt forward może mieć również charakter nierzeczywisty. W momencie rozliczenia nie dochodzi wówczas do fizycznej wymiany waluty pomiędzy stronami tego kontraktu. Rozliczenie polega na ustaleniu i wypłacie różnicy pomiędzy kursem terminowym (tj. z góry ustalonym kursem dla kontraktu forward) a kursem rzeczywistym waluty $\mathrm{w}$ dniu rozliczenia kontraktu w odniesieniu do kwoty kontraktu ${ }^{15}$.

Z kolei opcje uprawniają ich nabywcę (lecz nie nakładają na niego obowiązku) do zakupu (opcja kupna, call option) lub sprzedaży (opcja sprzedaży, put option) określonej ilości aktywów (instrumentu bazowego, którym może być również waluta) po ustalonej wcześniej cenie od wystawcy opcji w zamian za zapłatę wystawcy opcji premii opcji ${ }^{16}$. Zobowiązanym do świadczenia w przyszłości z kontraktu opcyjnego jest wyłącznie wystawca opcji, który zajmuje pozycję dłużnika, a uprawnionym wyłącznie nabywca opcji, który zajmuje pozycję wierzyciela ${ }^{17}$.

Nabywca opcji może żądać od wystawcy opcji realizacji kontraktu, czyli sprzedaży lub kupna w określonym momencie w przyszłości (w określonym dniu lub do oznaczonej daty) określonej ilości instrumentu bazowego po ustalonej z góry cenie albo do dokonania rozliczenia pieniężnego z tytułu różnicy pomiędzy tzw. ceną wykonania opcji a rynkową ceną instrumentu bazowego $\mathrm{z}$ dnia wykonania opcji ${ }^{18}$. Nabywca opcji

14 A. Dmowski, Opodatkowanie poszczególnych rodzajów pochodnych instrumentów finansowych - wybrane aspekty [w:] A. Dmowski, Opodatkowanie pochodnych instrumentów finansowych podatkiem dochodowym od osób prawnych, Warszawa 2014, LEX.

15 K. Ugolik, Usługodawcq $w$ ramach transakcji forward nierzeczywisty jest wyłqcznie podmiot profesjonalny świadczq̨cy tego typu usługi, „Monitor Podatkowy” 2015, nr 2, https://czasopisma.beck.pl/monitor-podatkowy/aktualnosc/uslugodawca-w-ramachtransakcji-emforwardem-nierzeczywisty-jest-wylacznie-podmiot-profesjonalnyswiadczacy-tego-typu-uslugi/ (dostęp: 28.12.2020 r.).

16 A. Chłopecki, Wprowadzenie - prawa pochodne jako instrumenty finansowe...

17 M. Bączyk, A. Jakubiec, P. Katner, M. Romanowski, Kontrakt opcyjny [w:] W.J. Katner, Prawo zobowiqzań - umowy nienazwane. System Prawa Prywatnego. Tom 9, Warszawa 2018, s. 706.

18 M. Bączyk, A. Jakubiec, P. Katner, M. Romanowski, Kontrakt opcyjny... s. 690. 
może również zrezygnować z realizacji tego kontraktu. Decyzja o rezygnacji jest w praktyce uzależniona od tego, jak będzie się kształtowała cena instrumentu bazowego na rynku w porównaniu do ceny ustalonej w kontrakcie opcyjnym. Przykładowo posiadacz opcji call skorzysta z prawa żądania odsprzedania waluty euro, jeżeli jej cena na rynku będzie wyższa niż cena ustalona w kontrakcie opcyjnym. Natomiast zrezygnuje z realizacji tego kontraktu, jeżeli cena waluty euro na rynku walutowym będzie niższa niż z określona w kontrakcie ${ }^{19}$.

Należy wskazać, że zabezpieczenie pewnego, bezpiecznego poziomu przychodów przed zmiennością kursów walut na rynkach walutowych nie zawsze oznacza osiągnięcie dodatniego wyniku na transakcjach zabezpieczających. Powyższe zależy od relacji kursu walutowego w dniu wykonania transakcji do kursu walutowego określonego w treści kontraktu terminowego typu forward czy opcji walutowej. Niekiedy przedsiębiorcy osiągają ujemy wynik na transakcjach zabezpieczających, ponieważ np. kursy walut były korzystniejsze niż te określone w kontraktach opcyjnych, ale konieczne było poniesienie kosztów premii opcyjnej. Innym przykładem może być sytuacja dotycząca kontraktów forward, w której przedsiębiorcy dostarczyli walutę po kursie niższym (określonym w kontrakcie) niż aktualny kurs walu$\mathrm{ty}^{20}$. Rozliczenie kontraktów forward i opcji walutowych wiąże się z koniecznością rozpoznania przychodów lub kosztów podatkowych ${ }^{21}$.

Zgodnie z art. 7b ust. 1 pkt 6 lit. b ustawy z dnia 15 lutego 1992 r. o podatku dochodowym od osób prawnych ${ }^{22}$ za przychody z zysków kapitałowych uważa się przychody z papierów wartościowych i pochodnych instrumentów finansowych, z wyłączeniem pochodnych instrumentów finansowych służących zabezpieczeniu przychodów albo kosztów niezaliczanych do zysków kapitałowych. W związku z tym przychody uzyskiwane na skutek zawierania kontraktów forward i opcji walutowych, których nabycie nie ma celu zarobkowego (spekulacyjnego), ale służy zabez-

19 A. Chłopecki, Wprowadzenie - prawa pochodne jako instrumenty finansowe...

20 Interpretacja indywidualna Dyrektor Krajowej Informacji Skarbowej z dnia 7 września 2018 r., 0111-KDIB1-2.4010.297.2018.1.AK.

21 Szerzej: A. Dmowski, Opodatkowanie pochodnych instrumentów finansowych podatkiem dochodowym od osób prawnych, Warszawa 2014.

22 Dz.U. z 2020 r. poz. 1406, ze zm.; dalej: u.p.d.o.p. 
pieczeniu przychodów z działalności gospodarczej prowadzonej na podstawie Zezwolenia SSE lub DoW, nie stanowią przychodów z zysków kapitałowych, o których mowa w art. 7b u.p.d.o.p. ${ }^{23}$ Taka klasyfikacja pozwala na sformułowanie wniosku, że zawieranie kontraktów zabezpieczających ryzyko walutowe stanowi działalność pomocniczą wobec podstawowej działalności przedsiębiorców określonej w Zezwoleniu SSE lub DoW.

Pojawia się $\mathrm{w}$ związku $\mathrm{z}$ tym pytanie - czy przedsiębiorcy mogą traktować tak powstające przychody i koszty jako przychody i koszty działalności zwolnionej z opodatkowania na podstawie Zezwolenia SSE lub DoW.

\section{Zwolnienie $\mathrm{z}$ podatku dochodowego od osób prawnych - uwagi ogólne}

Podstawę do przyznania pomocy publicznej w postaci zwolnienia z podatku dochodowego na podstawie u.w.n.i. stanowi DoW. W ramach u.s.s.e. podstawą do korzystania z pomocy publicznej jest Zezwolenie SSE.

Zgodnie $\mathrm{z}$ art. 3 u.w.n.i. wsparcie na realizację nowej inwestycji jest udzielane $\mathrm{w}$ formie zwolnienia od podatku dochodowego na zasadach określonych odpowiednio w przepisach Ustawy z dnia 26 lipca 1991 r. o podatku dochodowym od osób fizycznych ${ }^{24}$ albo w przepisach u.p.d.o.p.. Podobnie art. 12 ust. 1 u.s.s.e. odnosi się do zasad określonych w przepisach u.p.d.o.p. oraz u.p.d.o.f., wskazując, że dochody uzyskane z działalności gospodarczej prowadzonej na terenie Specjalnej Strefy Ekonomicznej (SSE) w ramach Zezwolenia SSE przez osoby prawne i osoby fizyczne prowadzące działalność gospodarczą są zwolnione od podatku dochodowego odpowiednio na zasadach określonych w przepisach u.p.d.o.p. lub w przepisach u.p.d.o.f.

Zgodnie z art. 17 ust. 1 pkt 34 u.p.d.o.p. wolne od podatku są dochody podatników podatku dochodowego od osób prawnych uzyskane z dzia-

23 Interpretacja indywidualna Dyrektora Krajowej Informacji Skarbowej z dnia 15 lutego 2018 r., 0111-KDIB1-3.4010.9.2018.2.JKT.

24 Dz.U. z 2020 r. poz. 1426, ze zm.; dalej: u.p.d.o.f. 
łalności gospodarczej prowadzonej na terenie SSE na podstawie Zezwolenia SSE, przy czym wielkość pomocy publicznej udzielanej w formie tego zwolnienia nie może przekroczyć wielkości pomocy publicznej dla przedsiębiorcy, dopuszczalnej dla obszarów kwalifikujących się do uzyskania pomocy w największej wysokości zgodnie z odrębnymi przepisami.

Podobny przepis znajduje się w art. 17 ust. 1 pkt 34a u.p.d.o.p. i odnosi się do zwolnienia, jakie przyznawane jest przedsiębiorcom na podstawie DoW. W jego treści wyrażenie sformułowane w pkt 34, tj. „prowadzonej na terenie SSE na podstawie Zezwolenia SSE”, zostało odpowiednio dostosowane do nowych przepisów poprzez zapis „określonej w DoW”.

W art. 17 ust. 4 u.p.d.o.p. doprecyzowano, że zwolnienia podatkowe, o których mowa w art. 17 ust. 1 pkt 34 u.p.d.o.p. (przyznawane na podstawie Zezwolenia SSE) i art. 17 ust. 1 pkt 34a u.p.d.o.p. (przyznawane na podstawie DoW), przysługują podatnikowi wyłącznie z tytułu dochodów uzyskanych z działalności gospodarczej prowadzonej na terenie strefy lub na terenie określonym w decyzji o wsparciu.

Jak wynika z powyższego, zwolnienie z podatku dochodowego dotyczy dochodu w rozumieniu u.p.d.o.p., czyli nadwyżki sumy przychodów uzyskanych z tego źródła przychodów nad kosztami ich uzyskania. Podatnik ma możliwość skorzystania $\mathrm{z}$ dostępnego limitu zwolnienia podatkowego, jeżeli spełnione są dwie przesłanki. Zwolnieniu z podatku dochodowego podlega dochód:

1. uzyskany z działalności gospodarczej prowadzonej na terenie SSE lub na terenie określonym w DoW; oraz

2. uzyskany z działalności gospodarczej prowadzonej na terenie SSE na podstawie Zezwolenia SSE lub odpowiednio z działalności gospodarczej określonej w DoW.

Zgodnie z poglądem prezentowanym przez NSA dochodem z działalności gospodarczej w rozumieniu art. 17 ust. 1 pkt 34 u.p.d.o.p. są wszelkie przysporzenia wynikające $\mathrm{z}$ działalności gospodarczej prowadzonej na terenie SSE, o ile tytuł ich otrzymania zawiera się w zakresie przedmiotowym działalności określonej w Zezwoleniu SSE ${ }^{25}$.

25 Wyrok NSA z dnia 15 lutego 2018 r., II FSK 245/16. 
Zwolnienie, o którym mowa w art. 17 ust. 1 pkt 34 u.p.d.o.p., ma charakter przedmiotowy i odnosi się do dochodów uzyskanych z określonego źródła, tj. działalności gospodarczej, z zastrzeżeniem, że działalność ta jest prowadzona w określonym miejscu i na podstawie stosownego Zezwolenia SSE, a więc $\mathrm{w}$ jego ramach i w granicach zakreślonych przedmiotem działalności gospodarczej ujętej w Zezwoleniu SSE ${ }^{26}$.

Kluczowe znaczenie przy ustaleniu zakresu korzystania z przedmiotowego zwolnienia ma zatem ustalenie znaczenia wyrażeń użytych w art. 17 ust. 1 pkt 34 i pkt 34a u.p.d.o.p.: dochody uzyskane z działalności gospodarczej „na podstawie” Zezwolenia SSE oraz „określonej w” DoW.

Zgodnie z art. 16 ust. 2 u.s.s.e. oraz art. 15 ust. 1 u.w.n.i. zarówno Zezwolenie SSE, jak i DoW określają przedmiot działalności gospodarczej, która będzie realizowana przez przedsiębiorcę i tym samym zwolniona z podatku dochodowego. Zakres zwolnienia podatkowego uzależniony jest od treści konkretnego Zezwolenia SSE czy konkretnej DoW ${ }^{27}$. W praktyce i w Zezwoleniach SSE, i w DoW opis działalności gospodarczej, którą deklaruje prowadzić przedsiębiorca, sprecyzowany jest na podstawie Polskiej Klasyfikacji Wyrobów i Usług (PKWiU) ${ }^{28}$. Natomiast ustawodawca nie doprecyzował w powołanych przepisach art. 16 ust. 2 u.s.s.e. oraz art. 15 ust. 1 u.w.n.i. w jaki sposób, a raczej do jakiego stopnia, przedmiot działalności gospodarczej powinien zostać skonkretyzowany w Zezwoleniu SSE czy DoW ${ }^{29}$.

26 Wyrok NSA z dnia 19 czerwca 2018 r., II FSK 1591/16, Wyrok NSA z dnia 30 czerwca 2014 r., II FSK 1727/12.

27 Wyrok NSA z dnia 15 maja 2014 r., II FSK 1457/12.

28 W pewnych przypadkach zakres działalności objętej Zezwoleniem określany jest na podstawie Polskiej Klasyfikacji Działalności (PKD). Por. A. Tałasiewicz (red.), Prawne i podatkowe aspekty prowadzenia działalności gospodarczej w Specjalnych Strefach Ekonomicznych, Warszawa 2010, s. 31, 132, 176.

Wyrok NSA z dnia 19 czerwca 2018 r., II FSK 1591/16. 


\section{Zakres zwolnienia z podatku dochodowego dochodów z działalności gospodarczej prowadzonej na podstawie Zezwolenia SSE}

Zgodnie ze słownikiem języka polskiego „na podstawie czegoś” oznacza 'opierając się na czymśs ${ }^{30}$. W orzecznictwie wskazuje się, że ustawodawca posłużył się określeniem „na podstawie”, a nie sformułowaniami pozwalającymi na bliższą konkretyzację określonych form aktywności gospodarczej, jak: „wymienione” czy też „wyszczególnione” w Zezwoleniu SSE. Zwrot „na podstawie” można natomiast postrzegać jak: 'stosownie do', 'w oparciu o'. Zdaniem Naczelnego Sądu Administracyjnego (NSA) z takim ujęciem nie koliduje również użyte $\mathrm{w}$ art. 12 u.s.s.e. określenie dochody uzyskane z działalności gospodarczej prowadzonej „w ramach Zezwolenia SSE"31.

NSA zwracał również uwagę, że w toku prowadzonej działalności gospodarczej podmiot strefowy może uzyskać przychód (dochód) wynikający bezpośrednio z wytworzonego produktu finalnego, na produkcję którego uzyskał Zezwolenie SSE, ale mogą to być również przychody związane pośrednio z prowadzoną produkcją wynikające np. z oszczędności czy też innowacji przeprowadzonych lub uzyskanych w trakcie procesu produkcji. Jeżeli taki przychód wiąże się ściśle z procesem produkcji, na który podmiot strefowy posiada Zezwolenie SSE, to również będzie on podlegać zwolnieniu na podstawie art. 17 ust. 1 pkt 34 u.p.d.o.p. Ograniczenie stosowania tego przepisu tylko do przychodów uzyskanych z tytułu zbycia produktów finalnych wytworzonych w SSE nie znajduje uzasadnienia, skoro zwolnienie to odnosi się do dochodów związanych z działalnością w SSE prowadzoną na podstawie Zezwolenia SSE, nie zaś do produktów wskazanych w Zezwoleniu SSE.

Ponadto NSA podkreślał, że powyższa interpretacja art. 17 ust. 1 pkt 34 u.p.d.o.p., wynikająca $\mathrm{z}$ odwołania się do funkcjonalnych reguł

30 S. Dubisz (red.), Uniwersalny słownik języka polskiego, Tom II, Warszawa 2003; hasło „na podstawie” Internetowy słownik języka polskiego, https://sjp.pwn.pl/szukaj/na\%20 podstawie.html (dostęp: 28.12.2020 r.).

31 Wyrok NSA z dnia 30 czerwca 2014 r., II FSK 1727/12, Wyrok NSA z dnia 19 czerwca 2018 r., II FSK 1591/16 oraz II FSK 1590/16. 
wykładni, nie jest niezgodna z językowymi regułami wykładni tego przepisu. W konsekwencji dla ustalenia, jakie dochody (uzyskiwane przez przedsiębiorcę prowadzącego działalność gospodarczą na terenie SSE) zwolnione będą $\mathrm{z}$ podatku dochodowego, konieczne jest uwzględnienie wszystkich elementów Zezwolenia SSE, które naprowadzają na preferowany zwolnieniem podatkowym rodzaj działalności. Przy ustalaniu zakresu zwolnienia należy uwzględnić szerszy kontekst, który wykracza poza językowe brzmienie jednego z elementów Zezwolenia SSE (wskazującego określony rodzaj działalności gospodarczej za pomocą kodów $\mathrm{PKWiU/PKD})^{32}$.

Poglądy te zostały wyrażone przez NSA w odniesieniu do możliwości zwolnienia z podatku dochodowego na postawie Zezwolenia SSE dochodów ze zbycia praw do emisji CO2 uzyskiwanych z działalności gospodarczej objętej tym Zezwoleniem SSE. W związku z tym, że proces produkcji był związany z emisją CO2, przedsiębiorcy byli zobowiązani do przedstawienia do umorzenia odpowiedniej ilości praw do emisji CO2. Na skutek ograniczenia emisji CO2 (np. poprzez zastosowanie nowych, bardziej ekologicznych technologii produkcji) przedsiębiorca posiadał nadwyżkę niewykorzystanych praw do emisji CO2, które następnie sprzedał.

W przywołanych wyrokach NSA wskazywał, że dochód ze sprzedaży nadwyżek limitów emisyjnych należy rozpoznać jako dochód uzyskany w ramach działalności podstawowej, wymienionej w Zezwoleniu SSE i w konsekwencji korzystający ze zwolnienia od podatku dochodowego na podstawie art. 17 ust. 1 pkt 34 u.p.d.o.p. Warunkiem takiej kwalifikacji jest wykazanie funkcjonalnego powiązania sprzedaży nadwyżek niewykorzystanych praw do emisji CO2 z działalnością gospodarczą określoną w Zezwoleniu SSE. Zdaniem NSA funkcjonalne powiązanie istnieje, jeżeli m.in.:

1. istnieje zależność między działalnością podstawową a nabyciem limitów emisyjnych;

2. nabycie limitów emisyjnych wiąże się wyłącznie z prowadzeniem wyszczególnionej w zwolnieniu działalności gospodarczej w zakresie działalności podstawowej;

32 Wyrok NSA z dnia 30 czerwca 2014 r., II FSK 1727/12, Wyrok NSA z dnia 19 czerwca 2018 r., II FSK 1591/16 oraz II FSK 1590/16. 
3. zbycie nadwyżek limitów emisyjnych klasyfikowane jest w ramach tej samej grupy statystycznej, przypisanej w Zezwoleniu SSE dla działalności podstawowej.

Zdaniem autorki powyższe rozważania NSA mogą mieć kluczowe znaczenie w kwestii zastosowania przedmiotowego zwolnienia w odniesieniu do omawianych instrumentów pochodnych ze względu na ich podobny charakter (tj. dochody niewynikające bezpośrednio ze sprzedaży wyrobów strefowych, ale powiązane z działalnością podstawową na podstawie Zezwolenia SSE). Konsekwentnie w celu określenia, czy dochody z kontraktów terminowych forward oraz opcji zawieranych przez przedsiębiorców w celu zabezpieczenia ryzyka kursowego transakcji zakupu/sprzedaży realizowanych na potrzeby działalności gospodarczej prowadzonej na podstawie Zezwolenia SSE mogą korzystać ze zwolnienia określonego w art. 17 ust. 1 pkt 34 u.p.d.o.p., analizie należy poddać, czy przedstawione przez NSA warunki istnienia powiązań funkcjonalnych zostaną spełnione w odniesieniu do tych dochodów.

Czynności podejmowane przez przedsiębiorców w celu zabezpieczenia wyników działalności gospodarczej prowadzonej na podstawie Zezwolenia SSE (czy też określonej w DoW) są nierozerwalnie związane z osiąganiem przychodów z tej działalności. W związku z tym, że pomoc publiczna udzielana jest $\mathrm{w}$ formie zwolnienia $\mathrm{z}$ podatku dochodowego, przedsiębiorca faktycznie z niej skorzysta, jeżeli będzie uzyskiwał dochody z działalności prowadzonej na podstawie Zezwolenia SSE (DoW) i byłby zobowiązany do zapłaty podatku dochodowego. Zawieranie kontraktów terminowych stanowi zatem gwarancję zastosowania zwolnienia, o którym mowa w art. 17 ust. 1 pkt 34 i pkt 34a u.p.d.o.p. Istnieje zależność między działalnością podstawową sprecyzowaną w Zezwoleniu SSE (DoW) za pomocą klasyfikacji PKWiU a zawieraniem kontraktów terminowych zabezpieczających dochody z tej działalności. Zapewnienie rozliczenia po założonym kursie wymiany wiąże się z zabezpieczeniem rozliczeń dokonywanych w ramach działalności gospodarczej określonej w Zezwoleniu SSE (DoW).

Odnosząc się do warunku trzeciego, z pisma Ośrodka Klasyfikacji i Nomenklatur Urzędu Statystycznego z dnia 23 listopada 2010 r. wynika, 
że zakup na potrzeby własne lub sprzedaż na własny rachunek przez przedsiębiorcę przyznanych uprawnień do emisji CO2 (związanych z produkcją płyt drewnopochodnych) nie jest działalnością odrębnie klasyfikowaną i mieści się w tej samej grupie PKD, co wskazana w Zezwoleniu SSE, w ramach której wyszczególniono produkcję płyt fornirowych. W tym kontekście należy wskazać, że operacje na instrumentach finansowych zabezpieczające ryzyko walutowe przy rozliczeniach dokonywanych w ramach działalności gospodarczej zwolnionej przedmiotowo z opodatkowania na podstawie art. 17 ust. 1 pkt 34 i pkt 34a u.p.d.o.p. nie stanowią niezależnych operacji spekulacyjnych oderwanych od podstawowej działalności przedsiębiorców.

Obowiązkiem przedsiębiorcy prowadzącego działalność w SSE jest wykazanie, że uzyskany przychód pochodzi z działalności prowadzonej na terenie SSE i został uzyskany z działalności wymienionej w Zezwoleniu SSE. Odnosi się to także do różnic kursowych oraz transakcji na pochodnych instrumentach finansowych (kontrakty terminowe, opcje) realizowanych $\mathrm{w}$ celu zabezpieczenia się przed ryzykiem kursowym. Mogą one zostać objęte zwolnieniem podatkowym z art. 17 ust. 1 pkt 34 u.p.d.o.p. tylko w takim zakresie, w jakim odnoszą się do transakcji zakupu materiałów i towarów niezbędnych do wytworzenia wyrobów oraz sprzedaży wyrobów spełniających warunek wytworzenia w SSE i w zakresie objętym Zezwoleniem SSE. W pozostałej części zarówno przychody ze sprzedaży wyrobów, jak i związane z tym różnice kursowe, a także transakcje na pochodnych instrumentach finansowych nie mogą być objęte zwolnieniem podatkowym ${ }^{33}$.

W konsekwencji zawieranie kontraktów forward i opcji nie stanowi samodzielnego przedmiotu działalności gospodarczej. Przychody z kontraktów terminowych zabezpieczających działalność prowadzoną na podstawie Zezwolenia SSE stanowią wobec tego przychody związane z prowadzeniem działalności gospodarczej w zakresie określonym w Zezwoleniu SSE za pomocą klasyfikacji PKWiU/PKD.

33 Wyrok Wojewódzkiego Sądu Administracyjnego we Wrocławiu z dnia 7 czerwca 2011 r., I SA/Wr 453/11 oraz z dnia 21 lipca 2011 r., I SA/Wr 767/11. 
W literaturze przedmiotu można odnaleźć stanowisko, że przychody finansowe stanowią przychody zwolnione z opodatkowania na podstawie Zezwolenia SSE pod warunkiem spełnienia podstawowych kryteriów zwolnienia. Tymi kryteriami są:

1. związek przychodu z działalnością określoną w Zezwoleniu SSE,

2. osiąganie przychodu z działalności prowadzonej na terenie SSE.

Według A. Allena korzystanie z kontraktów terminowych na zakup lub sprzedaż waluty w celu zabezpieczenia ryzyka walutowego dotyczącego działalności prowadzonej na terenie SSE jest uznawane za bezpośrednio związane z działalnością strefową ${ }^{34}$.

Podobny pogląd przedstawili P. Małecki oraz M. Mazurkiewicz: „Zwolnienie z podatku dochodów uzyskanych w SSE przysługuje podatnikowi wyłącznie z tytułu dochodów uzyskanych z działalności gospodarczej prowadzonej na terenie SSE. Zwolnione są wszystkie dochody uzyskane w SSE, w tym dochody z instrumentów finansowych"35.

Wydane zostały interpretacje indywidualne, a także wyroki Wojewódzkich Sądów Administracyjnych, w których wprost stwierdzano, że jeśli zawarcie umów dotyczących kontraktów terminowych związane jest z prowadzoną przez przedsiębiorcę działalnością w SSE, przychody i koszty z tym związane generują dochód z działalności prowadzonej przez przedsiębiorcę w SSE ${ }^{36}$.

34 A. Allen, Przychody z działalności strefowej [w:] A. Tałasiewicz, Prawne i podatkowe aspekty prowadzenia działalności w Specjalnych Strefach Ekonomicznych, Warszawa 2010, s. 192.

35 P. Małecki, M. Mazurkiewicz, CIT. Komentarz. Podatki i rachunkowość, Warszawa 2020, LEX.

36 Interpretacje indywidualne: Dyrektora Izby Skarbowej w Warszawie z dnia 20 marca 2013 r., IPPB3/423-555/11-6/S/13/MS, Dyrektora Izby Skarbowej w Katowicach z dnia 6 grudnia 2010 r, IBPBI/2/423-1168/10/AK, Dyrektora Izby Skarbowej w Poznaniu z dnia 19 grudnia 2008 r., ILPB3/423-608/08-3/ŁM oraz z dnia 15 kwietnia 2009 r., ILPB3/423-85/09-2/EK oraz z dnia 15 stycznia 2010 r., ILPB3/423-951/092/HS oraz z dnia 8 listopada 2010 r., ILPB3/423-678/10-2/MM oraz ILPB3/423678/10-3/MM, Wyroki WSA w Warszawie z dnia 16 października 2012 r., III SA/Wa 263/12 oraz z dnia 13 czerwca 2014 r., III SA/Wa 3066/13, Wyrok WSA we Wrocławiu z dnia 7 czerwca 2011 r., I SA/Wr 453/11; Wyroki WSA w Warszawie z dnia 23 marca 2017 r., III SA/Wa 934/16 oraz III SA/Wa 814/16 (obydwa wyroki zostały uchylone przez wyroki NSA z dnia 9 sierpnia 2019 r., II FSK 2762/17 i II FSK 2761/17). 
Również NSA wskazał, że skoro przedsiębiorca działający w SSE nie powiązał zawartych kontraktów terminowych z konkretnymi pozycjami (przepływami), które mogłyby być zabezpieczone, słuszne było stanowisko organów podatkowych, że zawarte transakcje na pochodnych instrumentach finansowych stanowią dodatkową działalność finansową przedsiębiorcy nieobjętą zwolnieniem podatkowym. O negatywnym dla przedsiębiorcy stanowisku zdecydowały kwestie dowodowe. Przedsiębiorca nie wykazał, że celem zawartych transakcji było zabezpieczenie dochodów z działalności podstawowej określonej w Zezwoleniu SSE. Organ podatkowy, Wojewódzki Sąd Administracyjny (WSA) czy NSA nie kwestionowały w tej sprawie możliwości zwolnienia z opodatkowania na podstawie art. 17 ust. 1 pkt 34 u.p.d.o.p. dochodów z rozliczenia kontraktów forward i opcji walutowych jako takiej ${ }^{37}$.

W ostatnich latach $\mathrm{w}$ orzecznictwie pojawił się pogląd, że wynik działalności związanej z pochodnymi instrumentami finansowymi, pomimo że zabezpieczają one uzyskiwanie określonych przychodów z działalności strefowej, powinien być alokowany do działalności opodatkowanej ${ }^{38}$. Jako argument wskazano, że brak wymienienia w Zezwoleniu SSE działalności gospodarczej dotyczącej instrumentów finansowych czy też innych operacji finansowych (usług finansowych) powoduje, że nie mogą one korzystać ze zwolnienia przedmiotowego, gdyż wykraczają one poza jego ramy. Nie można zgodzić się z tą argumentacją, ponieważ, jak zostało wskazane powyżej, wyrażenie „na podstawie” użyte w art. 17 ust. 1 pkt 34 u.p.d.o.p. wskazuje, że zwolnieniu z opodatkowania podlegają dochody związane z działalnością w SSE prowadzoną na podstawie Zezwolenia SSE, nie zaś dochody ze sprzedaży produktów/usług wskazanych w Zezwoleniu SSE.

Podkreślenia wymaga fakt, że w stanach faktycznych przedstawionych w powołanych wyrokach przedsiębiorcy prowadzili działalność

37 Wyrok NSA z dnia 13 grudnia 2016 r., II FSK 3357/14.

38 Wyrok WSA w Gliwicach z dnia 17 lutego 2015 r., I SA/Gl 1100/14, Wyrok WSA w Krakowie z dnia 23 czerwca 2017 r., I SA/Kr 358/17, Wyrok NSA z dnia 20 czerwca 2017 r., II FSK 711/17 oraz z dnia 30 sierpnia 2017 r., II FSK 1703/15 oraz z dnia 8 sierpnia 2019 r., II FSK 2762/17 i II FSK 2761/17. 
opodatkowaną i zwolnioną z opodatkowania na podstawie Zezwolenia SSE. Jednocześnie nie byli oni w stanie bezpośrednio przyporządkować dochodów uzyskiwanych w wyniku transakcji zabezpieczających do konkretnych transakcji zakupu/sprzedaży realizowanych na potrzeby działalności gospodarczej zwolnionej z opodatkowania na podstawie DoW.

Sądy w powołanych orzeczeniach (mimo że były one niekorzystne dla przedsiębiorców) dopuszczały możliwość objęcia zwolnieniem również innych dochodów pod warunkiem ich bezpośredniego związku z działalnością gospodarczą prowadzoną na podstawie Zezwolenia SSE. Zdaniem sądów o braku bezpośredniego związku kontraktów terminowych z działalnością podstawową wymienioną w Zezwoleniu SSE świadczy to, że transakcje odbywały się na podstawie odrębnych umów zawieranych między instytucjami finansowymi a przedsiębiorcą oraz zmierzały do zwiększenia dochodów przedsiębiorcy poprzez zapewnienie sobie korzystnego kursu wymiany waluty.

Zawieranie kontraktów terminowych oraz opcji walutowych w celu zabezpieczenia np. sprzedaży wyrobów strefowych pełni służebną funkcję wobec działalności gospodarczej zwolnionej z opodatkowania. Na gruncie zarówno art. ustawy z dnia 2 lipca 2004 r. o swobodzie działalności gospodarczej $^{39}$, jak i art. 3 ustawy z dnia 6 marca 2018 r. Prawo przedsiębiorców $^{40}$ definicja legalna działalności gospodarczej została oparta na konstytutywnej przesłance, jaką jest jej zarobkowy charakter. W aspekcie subiektywnym prowadzenie działalności w celu zarobkowym oznacza dążenie do osiągnięcia w wyniku prowadzonej działalności zysku ${ }^{41}$. Wykonywanie czynności, których celem jest zapewnienie określonej rentowności działalności określonej w Zezwoleniu SSE, wpisuje się zatem w definicję działalności gospodarczej, wspierając jednocześnie jej niezakłóconą kontynuację i rozwój.

39 Dz.U. z 2017 r. poz. 2168, ze zm.; akt uchylony.

40 Dz. U. z 2019 r. poz. 1292, ze zm.

41 K. Kruszewski, komentarz do art. 3 [w:] A. Pietrzak, Prawo przedsiębiorców. Komentarz, Warszawa 2019 za: M. Szydło, Pojęcie działalności gospodarczej na gruncie nowej ustawy o swobodzie działalności gospodarczej, „Przegląd Sądowy” 2005, nr 2, s. 25; E. Komierzyńska-Orlińska, komentarz do art. 3 Prawa Przedsiębiorców [w:] M. Wierzbowski, Konstytucja biznesu. Komentarz, Warszawa 2019. 
W literaturze przedmiotu odnaleźć można stanowisko, zgodnie z którym nie można jednoznacznie ocenić, czy przychody z transakcji na pochodnych instrumentach finansowych niejako a priori należy uznawać za przychody z działalności opodatkowanej, pomimo że mają one związek z działalnością strefową. Powodem tego jest lakoniczność przepisów regulujących te kwestie. Z jednej strony można argumentować, że zwolnienia podatkowe stanowią odstępstwo od zasady sprawiedliwości podatkowej (powszechności i równości opodatkowania) oraz że owo zwolnienie powoduje, że dochodzi do selektywnego transferu dóbr. Tym samym dochody związane $\mathrm{z}$ transakcjami zabezpieczającymi jako niewskazane wprost $\mathrm{w}$ ramach przedmiotu działalności ujętego w Zezwoleniu SSE (definiowanego co do zasady poprzez kody PKWiU/PKD) powinny podlegać opodatkowaniu na zasadach ogólnych. Z drugiej zaś strony, gdy związek danego instrumentu zabezpieczającego z prowadzeniem działalności strefowej jest ścisły i bezpośredni, należy uznać, iż wynik zrealizowany na takim instrumencie powinien być alokowany do wyniku z działalności zwolnionej. Autorzy wskazali, że każdy przypadek powinien być analizowany odrębnie, a głównym kryterium powinno być ustalenie, czy transakcje zabezpieczające mają związek z działalnością zwolnioną ${ }^{42}$.

Biorąc pod uwagę powyższe, należy wskazać, że dochody z kontraktów na zakup lub sprzedaż waluty zawieranych w celu zabezpieczenia ryzyka walutowego podlegają zaliczeniu do źródła przychodów działalności zwolnionej z opodatkowania, o ile transakcje służyły zabezpieczeniu przychodów z działalności określonej w Zezwoleniu SSE.

Wspomnieć należy, że orzeczenia sądów administracyjnych (a w szczególności NSA) posiadają niekiedy prawotwórczy charakter. Wpraktyce orzeczniczej sądów funkcjonuje precedens de facto. Mamy z nim do czynienia, gdy treść rozstrzygnięcia prawnego zawartego w orzeczeniu (które nie posiada mocy wiążącej) faktycznie wpływa na praktykę orzeczniczą sądów ${ }^{43}$.

42 K. Gil, A. Obońska, A. Wacławczyk, A. Walter (red.), Podatek dochodowy od osób prawnych. Komentarz, Warszawa 2019.

43 R. Marchaj, Prawotwórcza rola sq̨dów administracyjnych na przykładzie uchwały rady gminy w przedmiocie opłat za korzystanie z przedszkoli publicznych [w:] B. Dolnicki (red.), Sqdowe stosowanie prawa, Katowice 2014, s. 62. 
Niestety, funkcjonowanie w obrocie prawnym niekorzystnych dla przedsiębiorców wyroków NSA utrudniać może uzyskanie odmiennego rozstrzygnięcia na poziomie zarówno WSA, jak i NSA.

\section{Zakres zwolnienia z podatku dochodowego dochodów z działalności gospodarczej określonej w decyzji o wsparciu}

Jak już zostało wspomniane, ustawodawca, określając przedmiotowy zakres zwolnienia z art. 17 ust. 1 pkt 34 u.p.d.o.p., posłużył się wyrażeniem dochody uzyskane z działalności gospodarczej „na podstawie” Zezwolenia SSE. Natomiast w art. 17 ust. 1 pkt 34a u.p.d.o.p. użył sformułowania dochody uzyskane z działalności gospodarczej „określonej w” DoW. Zgodnie ze słownikami języka polskiego „określony” oznacza ‘sprecyzowany, wiadomy, pewny, jasny, wyraźny'44. Mogłoby to wskazywać na węższy zakres zwolnienia dochodów z działalności gospodarczej określonej w DoW.

W literaturze przedmiotu można odnaleźć stanowisko, które sugeruje węższy zakres zwolnienia w porównaniu do zwolnienia przyznanego na podstawie Zezwolenia SSE. Według autorów ustawodawca wprowadził dwie przesłanki, które musi spełnić dochód uzyskany na podstawie DoW, aby można go uznać za zwolniony z podatku dochodowego (do wysokości dostępnego limitu wynikającego z uzyskanej DoW), i są to:

1. prowadzenie działalności gospodarczej na terenie wskazanym w DoW; oraz

2. uzyskanie dochodu z działalności gospodarczej określonej w DoW (zgodnej z kodami PKWiU określonymi w tej DoW) ${ }^{45}$.

Jednocześnie w Objaśnieniach podatkowych ${ }^{46}$ wskazano, że również inne kategorie dochodów niż sprzedaż produktów/usług, które są nieroz-

44 S. Dubisz (red.), Uniwersalny słownik języka polskiego., Tom II, Warszawa 2003; hasło „określony” Internetowy słownik języka polskiego, https://sjp.pwn.pl/szukaj/ okre\%C5\%9Blony.html (dostęp: 28.12.2020 r.).

45 M. Sienkiewicz, M. Zwolenik, Polska Strefa Inwestycji. Czy zwolnieniu z opodatkowania powinien podlegać jedynie dochód generowany z nowej inwestycji?, „Przegląd Podatkowy” 2020, nr 2, s. 19-25. 
łącznie związane z prowadzoną na podstawie DoW działalnością produkcyjną lub usługową, objęte są zwolnieniem na podstawie art. 17 ust. 1 pkt 34a u.p.d.o.p.. Podkreślono, że dla zwolnienia z opodatkowania kluczowe jest wykazanie ścisłego, bezpośredniego i racjonalnego związku otrzymanego przysporzenia z przedmiotem działalności gospodarczej określonym w DoW. Jako przykład podano różnice kursowe powstałe w związku ze sprzedażą produktów.

Rozważania przedstawione $\mathrm{w}$ poprzednim rozdziale pozwalają na sformułowanie wniosku, że istnieje ścisły, bezpośredni i racjonalny związek między działalnością gospodarczą określoną w DoW a dochodami uzyskanymi na skutek zawarcia kontraktów terminowych, które zabezpieczają ryzyko walutowe przy transakcjach zakupu/sprzedaży realizowanych na potrzeby działalności gospodarczej zwolnionej z opodatkowania na podstawie DoW. W związku z tym dochody powstające z realizacji transakcji na pochodnych instrumentach finansowych powinny być zwolnione z podatku dochodowego jako dochody z działalności określonej w DoW.

Ponadto w Objaśnieniach podatkowych wskazano, że nie wszystkie dochody osiągane w związku z nową inwestycją będą podlegały zwolnieniu. Dziwi fakt, że jako przykład występowania takiej sytuacji podano uzyskiwanie dochodów z tytułu rzeczywistych kontraktów zabezpieczających typu forward. Wskazano, że mimo iż kontrakty zabezpieczające są zawarte $\mathrm{w}$ związku z realizacją nowej inwestycji, dochody lub koszty będą stanowiły odrębne źródło przychodów, ponieważ nie są źródłem dochodów z działalności określonej w DoW, lecz są dochodami uzyskanymi na skutek dokonania określonych, niezależnych operacji finansowych.

46 Objaśnienia podatkowe z dnia 6 marca 2020 r. dotyczące sposobu ustalania dochodu zwolnionego z opodatkowania podatkiem dochodowym, osiągniętego z działalności gospodarczej określonej w decyzji o wsparciu, o której mowa w ustawie z dnia 10 maja 2018 r. o wspieraniu nowych inwestycji; dalej: „Objaśnienia podatkowe” Autorka ma wątpliwość, czy Objaśnienia zostały wydane, czy są jedynie projektem. Należy zwrócić uwagę, że informacja o dacie wydania nie widnieje w pliku Objaśnień, ale została umieszczona jedynie na stronie internetowej www.gov.pl. Ponadto Objaśnienia nie zostały opatrzone podpisem Ministra Finansów ani osoby przez niego upoważnionej. Zatem powstaje wątpliwość, czy organy podatkowe w przyszłości nie będą próbowały negować ochrony prawno-podatkowej podatników, którzy zastosowali się do (projektu?) Objaśnień. 
W doktrynie wskazuje się, że objaśnienia podatkowe nie są wiążące - ani dla podatników, ani dla organów podatkowych, ani dla sądów ${ }^{47}$. Objaśnienia podatkowe nie mają mocy powszechnie obowiązujących źródeł prawa, dlatego też dochody związane z transakcjami zabezpieczającymi mogą podlegać zwolnieniu z opodatkowania z uwagi na ich związek z działalnością zwolnioną określoną w DoW. Zabezpieczenie się przed niekorzystnymi wahaniami kursów walut za pomocą kontraktów terminowych typu forward lub opcji działalności zwolnionej z opodatkowania na podstawie DoW nie może być traktowane w oderwaniu od tej działalności.

\section{Podsumowanie}

W ocenie autorki zawieranie umów na kontrakty terminowe typu forward oraz opcji na waluty, których celem jest zabezpieczenie ryzyka walutowego działalności podstawowej określonej w Zezwoleniu SSE (DoW), nie powinno być traktowane jako odrębna, niezależna działalność finansowa. Dokonywanie operacji na pochodnych instrumentach finansowych w celu zabezpieczenia transakcji zakupu lub sprzedaży realizowanych na potrzeby działalności gospodarczej określonej w Zezwoleniu SSE (DoW) jest ściśle i bezpośrednio związane z tą działalnością. Zgodnie z treścią artykułu istnieją argumenty przemawiające za tym, że dochody uzyskiwane z realizacji z tych transakcji zabezpieczających można uznać za zwolnione $\mathrm{z}$ podatku dochodowego jako dochody z działalności gospodarczej prowadzonej na terenie SSE na podstawie Zezwolenia SSE lub z działalności gospodarczej określonej w DoW.

Podkreślić należy, że „na podstawie czegoś” oznacza ‘opierając się na czymś, stosownie do, w oparciu o’. Jak słusznie zauważał NSA w swoich orzeczeniach, ustawodawca nie posłużył się w art. 17 ust. 1 pkt 34 u.p.d.o.p. sformułowaniami pozwalającymi na bliższą konkretyzację określonych form aktywności gospodarczej, jak: „wymienione” czy też „wyszczególnione” w Zezwoleniu SSE. W konsekwencji dochody uzyskane

47 K. Teszner, komentarz do art. 14a [w:] L. Etel (red.), Ordynacja podatkowa. Komentarz zaktualizowany, Warszawa 2020. 
w wyniku rozliczania kontraktów terminowych typu forward i opcji walutowych w części, w której dotyczą zabezpieczenia ryzyka kursowego działalności gospodarczej prowadzonej na terenie SSE, będą korzystały ze zwolnienia z podatku dochodowego od osób prawnych, o którym mowa w art. 17 ust. 1 pkt 34 u.p.d.o.p.

O wiele więcej wątpliwości pojawia się w odniesieniu do możliwości zwolnienia z opodatkowania dochodów z operacji zabezpieczających na pochodnych instrumentach finansowych jako dochodów z działalności gospodarczej określonej w DoW. Ustawodawca wskazał w art. 17 ust. 1 pkt 34a u.p.d.o.p., że wolne od podatku dochodowego są dochody z działalności gospodarczej określonej w DoW. Posłużył się zatem innym wyrażeniem niż w przypadku zwolnienia $\mathrm{z}$ art. 17 ust. 1 pkt 34a u.p.d.o.p., co mogłoby sugerować węższy zakres zwolnienia. Z drugiej strony w Objaśnieniach podatkowych dopuszczono możliwość zwolnienia $\mathrm{z}$ opodatkowania dochodów nierozłącznie związanych z działalnością gospodarczą prowadzoną na podstawie DoW. Kluczowe jest przy tym wykazanie ścisłego, bezpośredniego i racjonalnego związku otrzymanego przysporzenia z przedmiotem działalności gospodarczej określonym w DoW. Warunek ten jest bez wątpienia spełniony w odniesieniu do dochodów z kontraktów terminowych zawieranych przez przedsiębiorców w celu zabezpieczenia ryzyka kursowego transakcji zakupu/sprzedaży realizowanych na potrzeby działalności gospodarczej prowadzonej na podstawie DoW.

Podsumowując, zdaniem autorki dochody z realizacji kontraktów na zakup lub sprzedaż waluty podlegają zaliczeniu do źródła przychodów z działalności zwolnionej z opodatkowania, o ile transakcje służyły zabezpieczeniu ryzyka walutowego związanego z działalnością określoną w Zezwoleniu SSE lub DoW. 


\section{Bibliografia:}

Bączyk M., Jakubiec A., Katner P., Romanowski M., Kontrakt opcyjny [w:] W.J. Katner, Prawo zobowiqzań - umowy nienazwane. System Prawa Prywatnego. Tom 9, C.H. Beck, Warszawa 2018.

Chłopecki A., Opcje i transakcje terminowe. Zagadnienia prawne., Dom Wydawniczy ABC Warszawa 2001.

Choduń A., Koncepcja wykładni prawa Macieja Zielińskiego, „Ruch Prawniczy, Ekonomiczny i Socjologiczny” 2016, nr 4, s. 57-67.

Dmowski A., Opodatkowanie pochodnych instrumentów finansowych podatkiem dochodowym od osób prawnych, Wolters Kluwer, Warszawa 2014.

Dubisz S. (red.), Uniwersalny słownik języka polskiego. Tom II, Wydawnictwo Naukowe PWN, Warszawa 2003.

Etel L. (red.), Ordynacja podatkowa. Komentarz zaktualizowany, Lex/el., Warszawa 2020.

Gil K., Obońska A., Wacławczyk A., Walter A. (red.), Podatek dochodowy od osób prawnych. Komentarz, C.H. Beck, Warszawa 2019.

Komierzyńska-Orlińska E., komentarz do art. 3 ustawy Prawo Przedsiębiorców [w:] M. Wierzbowski , Konstytucja biznesu. Komentarz, Wolters Kluwer Polska, Warszawa 2019.

Małecki P., Mazurkiewicz M., CIT. Komentarz. Podatki i rachunkowość, Wolters Kluwer Polska, Warszawa 2020.

Marchaj R., Prawotwórcza rola sq̨dów administracyjnych na przykładzie uchwały rady gminy $w$ przedmiocie opłat za korzystanie z przedszkoli publicznych [w:] B. Dolnicki (red.), Sqdowe stosowanie prawa, Wydawnictwo Uniwersytetu Śląskiego, Katowice 2014.

Pietrzak A., Prawo przedsiębiorców. Komentarz, Wolters Kluwer Polska, Warszawa 2019.

Sienkiewicz M., Zwolenik M., Polska Strefa Inwestycji. Czy zwolnieniu z opodatkowania powinien podlegać jedynie dochód generowany z nowej inwestycji?, „Przegląd Podatkowy” 2020, nr 2, s. 19-25.

Spyra M., Prawo rynku instrumentów finansowych. Zagadnienia ogólne [w:] M. Stec (red.), Prawo instrumentów finansowych. System Prawa Handlowego Tom 4, C.H. Beck, Warszawa 2016.

Świderski A., Pochodne oraz strukturyzowane instrumenty finansowe - „sprawcy” czy „ofiary” ostatniego kryzysu finansowego? [w:] E. Fojcik-Mastalska, E. Rutkowska-Tomaszewska (red.), Bezpieczeństwo rynku finansowego, 
Wydział Prawa Administracji i Ekonomii Uniwersytetu Wrocławskiego, Wrocław 2010, s. 105-125.

Tałasiewicz A. (red.), Prawne i podatkowe aspekty prowadzenia działalności gospodarczej w Specjalnych Strefach Ekonomicznych, Wolters Kluwer Polska, Warszawa 2010.

Ugolik K., Usługodawcq $w$ ramach transakcji forward nierzeczywisty jest wyłqcznie podmiot profesjonalny świadczący tego typu usługi, , Monitor Podatkowy”, 2015, nr 2, https://czasopisma.beck.pl/monitor-podatkowy/aktualnosc/ uslugodawca-w-ramach-transakcji-emforwardem-nierzeczywisty-jestwylacznie-podmiot-profesjonalny-swiadczacy-tego-typu-uslugi/ (dostęp: 28.12.2020 r.).

Wierzbowski M., Sobolewski L., Wajda P. (red.), Prawo rynku kapitałowego. Komentarz, C.H. Beck, Warszawa 2018. 